\title{
ОЛЕКСАНДР ДОБРЖАНСЬКИЙ
} (OLEKSANDR DOBRZHANS'KYI)

Чернівецький національний університет ім. Юрія Федьковича, Україна

(Yurii Fedkovych Chernivtsi National University, Ukraine)

\section{Проблема опіки над місцями національної пам'яті в українсько-польських взасминах}

\section{The Problem of Taking Care of the Sites of National Remembrance in Ukrainian-Polish Relations}

Over previous decades, certain success has been achieved in the care of Ukrainian and Polish sites of national remembrance. However, recent events show that the situation has begun to deteriorate. Therefore, we need to look for ways to reach consensus on this issue.

Keywords: places of national remembrance, Orliat cemetery, Pikulice cemetery, Ukrainian Insurgent Army, Home Army (AK), Volhynia.

Сучасні суспільно-історичні стереотипи, що побутують у свідомості українців та поляків, $є$ наслідком спільної історії двох сусідніх народів, яка далеко не завжди була сповнена позитивними прикладами добросусідських відносин. Історично склалося так, що окрім мовної та культурної близькості українці та поляки, проживаючи на порубіжних територіях, були учасниками вкрай гострих конфліктів, опинялися по різні боки протистоянь. Впродовж лишень минулого XX століття, кордони між двома сусідніми державами змінювалися декілька разів, додаючи у міжнаціональні взаємини нових гострих протиріч, як то територіальні суперечки, суперечки щодо приналежності та реституції культурних цінностей, права розбудови та опіки над місцями національної пам'яті.

Беззаперечно, місця національної пам'яті українців та поляків $є$ одним із критеріїв підтримки нерозривного духовного зв'язку поколінь, свого роду ланками ланцюга історичного розвитку. Відповідно, втрата культурних цінностей, відрив їх від народів, мають негативні наслідки 
для їх цілісного та повноцінного національно-культурного розвитку. В цьому сенсі українсько-польські міжнаціональні відносини та співпраця у справі опіки над місцями національної пам'яті, особливо цвинтарями жертв війни та політичних репресій, виступають як одна із важливих складових сучасних міждержавних взаємин. Українсько-польське прикордоння $\epsilon$ місцем особливого скупчення таких місць: могил українців у Польщі та польських цвинтарів на Україні, що в силу численних трагічних подій XX століття рясними скупченнями з'явилися та примножилися на українсько-польському порубіжжі.

Після утвердження України як незалежної держави одним із нагальних до вирішення питань досить гостро постала проблема опіки над місцями національної пам'яті.

Відомо, що ще у 1988 році було створено Культурно-освітнє товариство поляків в Україні, серед головних завдань якого став захист польських історичних пам'яток в Україні'.

3 підписанням у травні 1992 року Договору про добросусідство, дружні відносини та співробітництво між Україною та Республікою Польща з'явилася законодавча підстава для реалізації планів щодо охорони та відновлення пам'яток².

Наступним кроком стало підписання у 1994 році Міжурядової угоди про охорону місць пам'яті і поховань жертв війни та політичних репресій. Проте, дана угода, по суті, не була практично реалізована, хоча завдяки старанням президентів двох сусідніх країн було відкрито цвинтар польських офіцерів у Харкові та пам'ятник жертвам польсько-українського протистояння на Волині. Однак, значно складніше вирішувалося питання $з$ похованням Львівських орлят на Личаківському цвинтарі Львова.

Конфлікт навколо польських військових поховань на Личаківці став свого роду «лакмусовим папірцем» у польсько-українських відносинах. Над розв'язанням цієї проблеми обидві сторони працювали понад десять років. Нарешті, 24 червня 2005 року, за участю президентів Польщі та України, на Личаківському цвинтарі були відкриті меморіал загиблим воїнам Української Галицької Армії та «Меморіал орлят». На плиті меморіалу, розташованій у центрі польських поховань, зроблено напис: «Тут

1 L.O. Zaškil'nâk, M.G. Krikun, İstoriâ Pol'sii: vìd najdavniših časìv do naših dnìv, LNU ìmenì İ. Franka, L'vìv 2002, c. 671.

2 Dogovìr miž urâdami Ukraïni ta Respubliki Pol'ŝa „, Pro dobrosusìdstvo, družnì vìdnosini ta spivrobitnictvo” vìd 18 grudnâ 1992 r., „Vìdomostì Verhovnoï Radi Ukraïni” 1992, № 45 , c. 613 . 
лежить польський солдат, полеглий за Вітчизну». На порталі колишнього меморіалу було збережено напис з міжвоєнного двадцятиліття «Вони померли, щоб ми жили вільно».

Питання «Цвинтаря орлят» - лише один із багатьох символів спільної українсько-польської історії. Більшість політиків та істориків сходяться на тому, що успішне вирішення цієї проблеми стало знаковою подією в українсько-польських взаєминах.

Проблеми пов’язані із відкриттям «Меморіалу орлят» яскраво проілюстрували і той факт, наскільки потужно у свідомості українського та польського суспільств вкоренилися взаємні негативні історично-суспільні стереотипи, а також те, 3 яким труднощами вони піддаються коректуванню та згладженню. Аналізуючи складнощі щодо узгодження та реалізації проекту слід пам'ятати і про те, що дане питання вирішувалося елітою обох суспільств: політиками, представниками місцевих органів влади, істориками, які не могли не зважати на державні домовленості та міжнародно-політичні взаємини країн. Пересічні ж українці та поляки сприймали дану проблему ще більш гостро та емоційно.

А між тим, не кращим чином виглядала ситуація з українським похованнями у Польщі. В період комуністичної влади тут було знищено цілі кладовища та окремі могили українців, на яких була національна символіка. Протягом багатьох повоєнних років представники української меншини не могли навіть мріяти про встановлення пам'ятників. Якщо десь 3'являвся обеліск чи таблиця, наприклад, на пошану жертв операції «Вісла», то вони трактувались як нелегальні. Встановлення на могилі таблиці із написом «Тут похований воїн УПА» розцінювалось як порушення законодавства. 31989 року розпочинається процес відновлення таких могил силами українських національних громад Польщі. Зокрема, першими було відновлено пам'ятники у Пикуличах, що поблизу Перемишля.

Щоправда, цей процес був досить складним. Постійні суперечки точилися навколо поховань та таблиць на згаданому військовому цвинтарі Січових Стрільців в Пикуличах. У двохтисячному році там було перепоховано 47 українців, воїнів УПА, яких було ексгумовано з сіл Бірча та Лішня, що біля м. Санок.

Українські поховання у Польщі у 90-х роках XX століття і в двохтисячних роках розшукувалися та впорядковувалися, головним чином, представниками української національної меншини у РП та волонтерськими молодіжними організаціями. На відміну від Польської держави Україна не виділяла таких значних коштів на розшук та впорядкування 
українських цвинтарів, i, як наслідок, на сьогоднішній день про складення повного реєстру українських могил у Польщі говорити рано. Тим не менше, українською стороною зроблено чимало. Наприклад, станом на 31 грудня 2014 року на кошти Волинської облдержадміністрації та товариства «Холмщина», а також різноманітних релігійних організацій було проведено роботи із вшанування української національної пам'яті у 19 місцях ${ }^{3}$.

Аналіз матеріалів 3МІ дозволяє зробити висновок, що роботи польської сторони, пов'язані із виявленням та впорядкуванням національних цвинтарів у селах та містечках України, досить рідко наштовхувалися на протидію з боку українських адміністративно-державних структур чи місцевих жителів, чого не можна сказати про польську сторону. На теренах Республіки Польща будь-які відновлювальні роботи досить часто викликали чималий і далеко не завжди позитивний резонанс з боку пересічних поляків, який, у свою чергу, часто «підігрівався» місцевими 3MI. Тим не менше, в попередні роки, не зважаючи на не завжди сприятливі умови, обидві сторони потрохи покращували ситуацію з опікою над місцями національної пам'яті.

Однак в останні два роки ситуація почала змінюватися на гірше. Це стосується особливо польської сторони. Як приклад на підтвердження даної тези наведемо ухвалу Сейму РП від 22 липня 2016 року «Про визнання подій на Волині у роки Другої світової війни геноцидом проти поляків» та вихід у польський прокат фільму В. Смажовського «Волинь». Однобічне і доволі викривлене трактування подій наносить велику шкоду міжнаціональним стосункам, які з такою скрупульозністю вибудовувалися впродовж останніх двадцяти п’яти років.

Наслідком такої різкої зміни польської суспільної думки щодо українсько-польської історії стали акти вандалізму у місцях національної пам'яті: руйнуються і оскверняються українські і польські кладовища по обидва боки кордону, а це аж ніяк не додає позитиву у міждержавні взаємини.

Цим користуються треті сили, які влаштовують різноманітні провокації, найгучнішим з яких у останній період є обстріл із гранатомета

3 Materìali potočnogo arhìvu upravlìnnâ ìnformacìjnoï diâl'nostì ta komunìkacìj z gromads'kìstû Volyns'koï oblasnoï deržavnoï admìnìstraciï (m. Luc'k). İnformaciâ pro uporâdkuvannâ ukraïns'kih mìsc' pam'âtì na teritoriï Lûblìns'kogo voêvodstva Respubliki Pol'ŝa stanom na 31.12.2014. 
Консульства РП у Луцьку вночі 29 березня 2017 року․․ Голова МЗС України Павло Клімкін прокоментував цю подію так: «Обурений провокацією проти Генконсульства Польщі у Луцьку. Це підлість від тих, хто проти нашої дружби з РП»5.

Такі геополітичні реалії вкрай негативно впливають на двосторонні взаємини, ставлячи під сумнів напрацювання політичної та наукової еліти двох країн, ризикуючи ще більше ускладнити і загострити міжнаціональні протиріччя. Тому першочерговим завданням для нинішньої влади і наукової еліти обох країн $є$ проведення виваженої і послідовної політики спрямованої на подальше подолання негативних історико-суспільних стереотипів. Адже саме від цього залежать міжнаціональні взаємини українців і поляків та міжнародно-політичний клімат у Центрально-Східній Європі.

\section{Bìblìografîâ}

Dogovir miž urâdami Ukraïni ta Respubliki Pol'sa , Pro dobrosusìdstvo, družnì vìdnosini ta spivvrobitnictvo” vìd 18 grudnâ 1992 r., „Vìdomostì Verhovnoï Radi Ukraïni” 1992, № 45.

Klimkin prokomentuvav obstril konsul'stva u Luc'ku, www.unian.ua/politics/1847694-klimkin-prokomentuvav-obstril-konsulstva-polschi-u-lutsku-fotoreportaj.html.

Materìali potočnogo arhìvu upravlìnnâ ìnformacìjnoï diâl'nostì ta komunìkacìj z gromads'kìstû Volyns'koï oblasnoï deržavnoï admìnìstraciï (m. Luc'k). Ìnformaciâ pro uporâdkuvannâ ukraïns'kih mìsc' pam'âtì na teritoriï Lûblìns'kogo voêvodstva Respublìki Pol'ŝa stanom na 31.12.2014.

Obstril iz granatometa Konsul'stva Pol'sì u Luc'ku - ce provokaciâ ,tret'oï sili” - pol's 'ka reakciâ, www.radiosvoboda.org/a/28398281.htm.

Zaškil'nâk L.O., Krikun M.G., İstoriâ Pol'ŝi: vìd najdavniših časìv do naših dnìv, LNU ìmenì Ì. Franka, L’vìv 2002.

4 Obstril ì granatometa Konsul'stva Pol'sì u Luc'ku - ce provokaciâ , tret'oï sili" - pol's'ka reakciâ, www.radiosvoboda.org/a/28398281.htm (dostup: 21.04.2018).

5 Klimkin prokomentuvav obstril konsul'stva u Luc'ku, www.unian.ua/politics/1847694klimkin-prokomentuvav-obstril-konsulstva-polschi-u-lutsku-fotoreportaj.html (dostup: 21.04.2018). 